\title{
A Constitutional Path to Fair Representation for the Poor
}

Bertrall L. Ross $I I^{*}$

\section{INTRODUCTION}

The Tax Cuts and Jobs Act (TCJA) represented the crowning achievement of the first year of unified Republican control of the federal government's political branches. ${ }^{1} \quad$ President Donald Trump and Republicans in Congress sold the Act as a tax cut that would benefit the middle class. In an apparently coordinated effort, President Trump, Senate majority leader Mitch McConnell, and Speaker of the House Paul Ryan issued statements trumpeting the $\$ 2,000$ tax cut that the median income household of four would receive in $2018 .^{2}$

In opposing the tax bill, Democrats also tried to position themselves as champions of the middle class. Democrats blasted the bill as a giveaway to special interest groups and wealthy with little to no tax relief for the middle class. ${ }^{3}$ According to Senate Minority Leader Chuck

* Chancellor's Professor of Law, Berkeley Law, University of California.

1. Tax Cuts and Jobs Act, Pub. L. No. 115-97, 131 Stat. 2054 (2017).

2. President Donald Trump, Remarks by President Trump and American Taxpayers on Tax Reform (Dec. 13, 2017), https://www.whitehouse.gov/briefings-statements/remarks-president-trumpamerican-taxpayers-tax-reform/; Press Release, Representative Paul Ryan, Speaker Ryan's Floor Remarks on the Tax Cuts and Jobs Act (Dec. 19, 2017), https://www.speaker.gov/pressrelease/speaker-ryans-floor-remarks-tax-cuts-and-jobs-act; Senator Mitch McConnell, Tax Bill Tells Middle Class Americans “We Heard You," Fox News (Dec. 20, 2017), http://www.foxnews.com/ opinion/2017/12/20/sen-mitch-mcconnell-tax-bill-tells-middle-class-americans-heard.html. The tax cut resulted from an increase in the stadard deduction, a decreate in marginal tax rates, and an increase and expansion of the child tax credit. See Tax Foundation Staff, Preliminary Details and ANALYSIS OF THE TAX CUTS AND JOBS ACT 3-4 (Rachel Shuster ed., 2017), https://files.taxfoundation.org/20171220113959/TaxFoundation-SR241-TCJA-3.pdf (describing the details of the Tax Cut and Jobs Act). According to Republicans, the benefits to the middle class went beyond the direct tax cuts they would receive. Even those tax benefits that went to corporations and the wealthy, Republican supporters asserted, would eventually trickle down to the middle class through more and better jobs and higher wages. See Ben White, GOP Places Risky Bet on Trickledown Tax Cut, Politico (Nov. 30, 2017, 5:04 AM), https://www.politico.com/story/ 2017/11/30/republicans-trickle-down-tax-cut-196333 ("Republicans are counting on predictions from the administration that the corporate tax cuts will produce as much as $\$ 4,000$ per year in extra pay for households and a 0.4 percent boost to annual economic growth ....").

3. See, e.g., Senator Chuck Schumer, Schumer Statement on GOP Tax Bill (Dec. 1, 2017), https://www.democrats.senate.gov/newsroom/press-releases/schumer-statement-on-gop-tax-bill 
Schumer, the passage of the tax bill "will be the first day of a new Republican party - one that raises taxes on the middle class, abandoning its principles for its political paymasters." 4 House Minority Leader Nancy Pelosi described the Act as "written first and foremost for the wealthiest one percent, not middle class families trying to get ahead."

The congressional committee responsible for providing spending and revenue estimates to Congress, the non-partisan Joint Committee on Taxation, issued a report on the TCJA that provided support for both sides of the debate. ${ }^{6}$ In support of the Republican claims, the report showed that prior to the expiration of the individual tax cuts in 2025, individuals with annual incomes greater than $\$ 30,000$ would pay less in taxes. ${ }^{7}$ But in support of the Democratic claims, the report also showed that in 2027, after the individual tax cuts expired, individuals with annual incomes between $\$ 30,000$ and $\$ 75,000$ would pay more in taxes than they would under the tax code that preceded the TCJA. ${ }^{8}$

As the two parties fought back and forth on the question of how the TCJA would affect the middle class, they ignored a clear impact of the law. The poor would be the only group harmed by the law both prior to

(describing the bill as "chock full of special interest giveaways" that "will stuff even more money in the pockets of the wealthy and the biggest corporations, while raising taxes on millions in the middle class").

4. Schumer, supra note 3.

5. Press Release, Representative Nancy Pelosi, Pelosi Statement on Senate Passage of GOP Tax Scam (Dec. 2, 2017), https://www.democraticleader.gov/newsroom/12217-2/.

6. See Joint COMm. on TAXation, Distributional EFFects of the Conference Agreement For H.R. 1, THE "TAX Cuts AND Jobs ACT" (JCX-68-17), (Dec. 18, 2017), https://www.jct.gov/publications.html?func=startdown\&id=5054; see also Congressional Budget Act, 2 U.S.C. § 601(f) (2012) (establishing the Joint Committee on Taxation's estimates of revenue and spending as the official estimate for all congressional tax legislation).

7. JOINT COMM. ON TAXATION, supra note 6, at 1-3. The report showed that benefits from the reduction in marginal tax rates and expansion of the child tax credit would outweigh the costs from the reduction and elimination of deductions, the change in the inflation measure on which tax rates are calculated, and the elimination of the Affordable Car Act's individual mandate. See id.

8. Id. at 4-5. Even though the marginal tax rates, deductions, and the child tax credit would return to the pre-TCJA levels after the expiration of the individual tax cut in 2025, the permanent changes in the inflation measure for tax rates and the permanent elimination of the Affordable Care Act's individual mandate would leave the middle class worse off. See id.; see also Andrew Van Dam, The Essential Tradeoff in the Republican Tax Bill, in One Chart, WASH. Post (Dec. 16, 2017), https://www.washingtonpost.com/news/wonk/wp/2017/12/16/the-essential-tradeoff-in-therepublican-tax-bill-in-one-chart/?utm_term=.a660f5db2158 (describing how the permanent repeal of the Affordable Care Act and the change in the inflation index for tax brackets will increase taxes on individuals in the long run); Michael Hiltzik, The Chained CPI: Another Secret Tax Hike for the Middle Class Slipped Into the GOP Tax Bills, L.A. TIMES (Nov. 21, 2017, 11:05 AM), http://www.latimes.com/business/hiltzik/la-fi-hiltzik-chained-cpi-tax-bill-20171121-story.html (describing the effect of the shift from indexing tax brackets to the Consumer Price Index to indexing tax brackets to the chained Consumer Price Index and concluding that the shift is "all about taking more money from working Americans and sending it up the income ladder to the wealthy"). 
and after the expiration of the temporary provisions of the Act. By 2021, individuals with annual incomes below $\$ 30,000$ comprise the only income class that will pay more in taxes under the TCJA than under the current tax code. ${ }^{9}$ This income class would continue to pay more in taxes through the expiration of the individual tax cut provisions in $2025 .{ }^{10}$ Despite this clear evidence, neither the Republicans touting the bill nor the Democrats opposing the bill addressed the negative impact of the law on the poor. ${ }^{11}$

The fact that no champion of the poor stood up might seem shocking given that over forty million Americans lived below the poverty line $(12.7 \%)$ in 2016 and as recently as $2014,51 \%$ of Americans made less than $\$ 30,000$ per year. ${ }^{12}$ But the lack of advocacy for the lower income class in the TCJA debates is consistent with recent empirical findings about the poor's representation in the political process. In an analysis of the relationship between the policy preferences of different income classes and Senate roll call votes in the late 1980s and early 1990s, political scientist Larry Bartels found that senators were very responsive to highincome constituents, moderately responsive to middle-income constituents, and not at all responsive to low-income constituents. ${ }^{13}$ Another political scientist, Martin Gilens, has found that on issues for which the preferences of the different income groups diverge, only the policy preferences of the affluent voters are positively and statistically

9. See Joint COMm. On TAXATION, supra note 6, at 2 (showing that by 2021, individuals making less than $\$ 10,000$ will receive a tax cut totaling $\$ 60$ million while those making between $\$ 10,000$ and $\$ 30,000$ will pay nearly $\$ 4$ billion more in taxes).

10. See id. at 3-4 (showing individuals making less than $\$ 30,000$ will be paying $\$ 5.74$ billion more in taxes by 2023 and $\$ 6.14$ billion more in taxes by 2025). The combination of the shift in the measure of inflation for tax brackets, the elimination of the Affordable Care Act's individual mandate, and Republican refusal to make the expanded child tax credit refundable for those who do not pay enough in federal taxes contributed to the TCJA's tax increase on the poor. See Doyle McManus, What's Missing from the GOP Tax Bill? Just About Anything That Would Help the Working and Middle Classes, L.A. Times (Dec. 17, 2017, 4:05 AM), http://www.latimes.com/opinion/op-ed/la-oemcmanus-taxes-missing-20171217-story.html (describing how the different tax changes provide little benefit to the working poor).

11. In the absence of strong and politically connected advocates for the poor that could feed the media with information about the law's negative impact on the poor, which would raise the saliency of the issue, very few media outlets addressed the issue leaving both Democrats and Republicans free to ignore the issue. See Dara Z. Strolovitch, Affirmative Advocacy: Race, Class, and GENDER IN INTEREST GROUP POLITICS 113-120 (2007) (finding a lack of representation of economic issues affecting low interest groups among advocacy organizations, particularly organizations focusing on identity-based issues).

12. Jessica L. Semega et AL., U.S. Census Bureau, InCOME AND Poverty IN THE United STATES: 201613 (2017), https://www.census.gov/content/dam/Census/library/publications/2017/ demo/P60-259.pdf ; Wage Statistics for 2014, SOC. SECURITY ADMIN., (last visited Apr. 63, 2018), https://www.ssa.gov/cgi-bin/netcomp.cgi?year=2014.

13. Larry M. Bartels, Unequal Democracy: The Political Economy of the NeW GILDED AGE 252-82 (2008). 
significantly associated with policy outcomes. ${ }^{14}$ There is no statistically significant relationship between the preferences of median and lowincome voters and policy outcomes. ${ }^{15}$ This pattern held for the economic policy issues Gilens examined, which include redistributive policies involving the minimum wage, unemployment benefits, corporate regulations, and income taxes. ${ }^{16}$

What explains this lack of representation for the poor? Many point to the campaign finance and lobbying system that rewards with influence those who have money to contribute and spend in support of campaigns. ${ }^{17}$ This is unlikely to change in the current campaign finance regulatory context constitutionalized by the Supreme Court in Citizens United v. Federal Election Commission, which advantages the wealthy by providing for the free flow of money into politics. ${ }^{18}$ Others point to a related factorthe lack of elected representatives from working class or poor backgrounds. ${ }^{19}$ The demand for money to run a successful campaign means that those who either have money or know people with money have an advantage in running for office. The poor's lack of descriptive representation, which is also unlikely to change in the current campaign

14. Martin Gilens, AfFluence and Influence: Economic Inequality and Political POWER IN AMERICA 79-83 (2012).

15. Id. at 81,86 .

16. Id. at $112-15$.

17. See Bertrall L. Ross II, Addressing Inequality in the Age of Citizens United, 93 N.Y.U. L. REV. (forthcoming 2018) (describing the political advantages of the wealthy produced by our campaign finance and lobbying system and proposals to reduce these advantages); see also Editorial Board, The Tax Bill that Inequality Created, N.Y. TIMES (Dec. 16, 2017), https://www.nytimes.com/2017/12/16/opinion/sunday/tax-bill-inequality-created.html (accounting for the relationship between political inequality from the campaign finance system and policy outcomes).

18. See Citizens United v. Fed. Election Comm'n, 558 U.S. 310, 365 (2010) (holding that as political speech is protected by the First Amendment, the government may not prevent corporations from spending money to support or denounce candidates during elections); see also Wendy L. Hansen et al., Abstract, The Effects of Citizens United on Corporate Spending in the 2012 Presidential Election, 77 J. POL. 535, 535 (2015) ("The 2012 presidential election saw a 594\% increase in independent expenditures from the 2008 election ... leaving little doubt that the Supreme Court's landmark 2010 Citizens United decision opened the campaign spending floodgates."); Douglas M. Spencer \& Abby K. Wood, Citizens United, States Divided: An Empirical Analysis of Independent Political Spending, 89 IND. L.J. 315, 347 (2014) (finding, through an experiment comparing states with and without bans on independent expenditures prior to Citizens United, that the decision caused an increase in independent spending).

19. See nicholas Carnes, White-Collar Government: The Hidden Role of Class in ECONOMIC POLICY MAKING 20 (Benjamin I. Page et al. eds., 2013) (finding that only about $6 \%$ of congress members serving between 1999 and 2008 held a working class job at some point in their careers). 
finance regulatory context, might contribute to their lack of substantive representation in the democratic process. ${ }^{20}$

Still others attribute the underrepresentation of the poor to the fact that the poor do not vote as much as other income classes. ${ }^{21}$ Since the early 1970 s, there has been a consistent $25-35 \%$ turnout gap between individuals in the lowest and highest income quintiles. ${ }^{22}$ To the extent that there is a correlation between turnout and representation, the failure of the poor to vote will lead to less representation in the political process.

Scholars have conventionally attributed the low turnout of the poor to cost barriers of voting. ${ }^{23}$ But when states and localities have reduced the cost barriers to voting, the turnout of the poor has either remained unchanged or declined. ${ }^{24}$ This paradox has led scholars to search for other explanations of the poor's low turnout.

In the 1990s, mobilization scholars found evidence that the poor's lack of turnout is connected to candidates' lack of engagement with this group during the electoral process. ${ }^{25}$ They identified a vicious cycle in which the poor, not perceiving benefits from voting in the form of laws and policies advancing their needs and interests, have mostly stayed home on election

20. See id. at 25-33 (finding a relationship between descriptive and substantive representation, but the author's data was limited to a small sample of congresspersons with low income and working class backgrounds).

21. Political scientist V.O. Key famously asserted, "The blunt truth is that politicians and officials are under no compulsion to pay much heed to classes and groups of citizens that do not vote." V.O. Key, JR., Southern Politics In State AND NAtion 527 (1st ed. 1949). Since Key's famous assertion, a number of political scientists have questioned the relationship between voting and representation, finding on the basis of survey evidence that the preferences, ideologies and interests are indistinguishable. See, e.g., RAYMOND E. WOLFInGER \& STEVEN J. ROSENSTONE, Who Votes? 104-14 (1980); John Sides, Eric Schickler, \& Jack Citrin, If Everyone Had Voted, Would Bubba and Dubya Have Won?, 38 PRESIDENTIAL STUD. Q. 521, 522-23 (2008) ("The main conclusion of research on the relationship between turnout and electoral outcomes in congressional, Senate, and presidential elections is that the impact of higher turnout is both variable and usually small.") (internal citations omitted).

22. Jan E. Leighley \& Jonathan Nagler, Who Votes Now? Demographics, Issues, INEQUALITY, AND TURNOUT IN THE UNITED STATES 1 (2014); Jan E. Leighley \& Jonathan Nagler, Class Bias in the U.S. Electorate, 1972-2004 24 (Am. Political Sci. Ass'n, Aug. 26, 2006);.

23. According to the resource model of participation, the nonvoting of the poor is best explained by the fact that they lack the resources in terms of eduation, employment, and income to overcome the cost barriers to voting. See WOLFINGER \& ROSENSTONE supra note 21, at 24 (finding that education has the most powerful independent effect on turnout); SidNeY VERBA \& NORMAN H. NIE, PARTICIPATION IN AMERICA: POlitical DEMOCRACY AND SOCIAL EQUAlity 13-15 (1972) (finding that job, education, and income are the primary determinants of political participation).

24. Richard A. Brody, The Puzzle of Participation in America, in THe New AMERICAN Political System 287, 291-99 (Anthony King ed., 1978).

25. See SteVen J. Rosenstone \& John Mark Hansen, Mobilization, Participation, and DEMOCRACY IN AMERICA 213 (Bruce Nichols \& Robert Miller eds., 1993) (finding as a source of the poor's decline of interest in politics, the "changing pattern[s]of mobilization by parties, campaigns, and social movements" that focused less on the needs of the politically marginalized). 
day. ${ }^{26}$ Candidates and elected representatives have in turn responded to the poor's nonvoting by ignoring their interests and needs in the lawmaking process. ${ }^{27}$ If this account of the relationship between participation and representation is correct, breaking this vicious cycle may be the key to fairer representation for the poor.

Can law be used to break the cycle of under-representation and politically empower the poor? One response might be to follow the voting rights model used to empower racial minorities. The Voting Rights Act has secured fairer representation for communities of color through enforcement of a group-based right to representation in the political process. ${ }^{28}$ However, there are two overwhelming obstacles to applying the VRA model of fair representation to the poor. First, the original VRA was the product of social movement pressure from African Americans and others on Congress and the President to protect the voting rights of people

26. Id. at 6 ("' $[\mathrm{P}]$ eople who see more at stake in politics, whether because policies affect them more, identities beckon them more, options appeal to them more, or duty calls them more, are more attracted by the many benefits that politics offers").

27. See BARTELS, supra note 13; GILENS, supra note 14.

28. Congress first advanced a statutory mandate of racial minority representation in the political process through its amendments to Section 2 of the Voting Rights Act. Section 2 of the amended Voting Rights Act prohibits states or political subdivisions from imposing any voting qualification that "results in a denial or abridgment of the right of any citizen of the United States to vote on account of race or color." 52 U.S.C. $§ 10301$ (a) (2012) (originally enacted as 42 U.S.C. § 1973(a)). The section continues:

A violation of subsection (a) is established if, based on the totality of circumstances, it is shown that the political processes leading to nomination or election in the State or political subdivision are not equally open to participation by members of a class of citizens protected by subsection (a) in that its members have less opportunity than other members of the electorate to participate in the political process and to elect representatives of their choice.

52 U.S.C. § 10301(b) (Supp. III 2015) (originally enacted as 42 U.S.C. $§ 1973(b)$ ). In adopting the amended VRA, Congress overturned the Supreme Court case of Mobile v. Bolden, 446 U.S. 55 (1980), which interpreted Section 2 of the 1965 VRA to require that challenges prove that the state acted with discriminatory intent in establishing voting barriers. See H.R. REP. No. 97-227, at 2 (1981) ("The amendment is necessary because of the unsettling effect of the decision of the U.S. Supreme Court in City of Mobile v. Bolden, 446 U.S. 55 (1980). The amendment clarifies . . that proof of purpose or intent is not a prerequisite to establishing voting discrimination violations in Section 2 cases.”). But in doing so, Congress made clear through the amended VRA the goal of increasing the number of racial minorities in elected office. See 52 U.S.C. $\$ 10301$ (b) (Supp. III 2015) (originally enacted as 42 U.S.C. § 1973(b)) (finding as a relevant circumstantial factor under the totality of the circumstances test, "[t]he extent to which members of a protected class have been elected to office in the State of political subdivision"); H.R. REP. NO. 97-227, at 8 (finding as evidence of the lack of progress under the VRA the fact that "[t]he number of minority elected officials is still a fraction of the total number of elected officials"). In a subsequent case, the Court established a three-factor test that defined the statutory right in group-based representational terms. Thornburgh v. Gingles, 478 U.S. 30 (1986). In order to prove a violation under Section 2 of the VRA, the challenger to the districting practice must prove: (1) "the minority group ... is able to demonstrate that it is sufficiently large and geographically compact to constitute a majority in a single-member district," (2) "the minority group . . . is politically cohesive," and (3) "the white majority votes sufficiently as a bloc to enable it ... usually to defeat the minority's preferred candidate." Id. at $50-51$. 
of color. ${ }^{29}$ The poor currently lack a social movement that would be able to put similar pressure on the political branches to adopt a statute like the VRA for the poor.

Given this political reality, constitutional law is a natural place to turn in seeking a VRA-like model of fair representation for the poor. ${ }^{30}$ After all, the courts are sometimes willing to protect the rights of the marginalized when the political branches will not. But a second obstacle emerged nearly five decades ago, when the Supreme Court appeared to close down this constitutional path to securing group-based representation for the poor. In 1971, in the context of the War on Poverty, a group of African American poor residents in Marion County, Indiana advanced a constitutional claim for fair representation that might have broken the cycle of under-representation. ${ }^{31}$ The focus of the constitutional claim was on a districting practice alleged to deny the African American poor in Marion County the opportunity to elect candidates more in proportion with their share of the population. ${ }^{32}$ The Supreme Court in Whitcomb v. Chavis rejected the claim, finding the group's lack of proportional representation to be constitutionally irrelevant in the absence of evidence that poor individuals had less opportunity to participate in the political process and elect candidates of their choice. ${ }^{33}$

By rejecting the group-based model of representation, did the Whitcomb Court shut the door to any opportunity for the poor to secure fair representation through the Constitution? In this article, I argue that while the Court shut one door, it left another open. Even after Whitcomb, the poor continue to be entitled to fair representation under the Fourteenth Amendment's Equal Protection Clause. But rather than through a groupbased right to representation, constitutional doctrine secures fair representation for politically marginalized groups like the poor through a guarantee of full and effective participation in the political process. ${ }^{34}$

The Court effectuated part of this constitutional guarantee in two cases decided in the 1960s striking down mal-apportioned congressional and

29. See, e.g., Jason Mazzone \& Stephen Rushin, From Selma to Ferguson: The Voting Rights Act as a Blueprint for Police Reform, 105 CAL. L. REV. 263, 286-88 (2017) (describing the catalyzing effect of civil rights protest and the violent confrontation between the police and protesters in Selma, Alabama on the passage of the Voting Rights Act).

30. Famously, in footnote four of United States v. Carolene Products, the Court tentatively announced as a judicial role the close scrutiny of laws that discriminate against discrete and insular minorities. United States v. Carolene Prods. Co., 304 U.S. 144, 152 n.4 (1938).

31. 403 U.S. $124,128-29$ (1971).

32. Id.

33. Id. at 160 .

34. See infra Part III. 
state legislative districts as inconsistent with one-person, one vote. ${ }^{35}$ The one person, one vote requirement that every persons vote count the same, secured to individuals full participation in the political process through equipopulous districts. ${ }^{36}$ But the guarantee to individuals of full participation did not ensure they would be effective participants in the political process. Instead, as the Court acknowledged in a case right after it established one person, one vote, the votes of individuals could be unconstitutionally cancelled out or minimized in equipopulous districts. ${ }^{37}$ In this Article, I argue that this right to effective participation, which has never been fleshed out in doctrine, should be understood to require states to draw competitive districts as a means to incentivize candidates to vie for the votes of members of all groups. ${ }^{38}$ Doing so would ensure the effectiveness of every individual's votes by preventing political actors from ignoring or overlooking any persons' vote without electoral consequences. $^{39}$

This article proceeds in three parts. In Part I, I describe the constitutional claim for group-based representation that the African American poor advanced, and the Court ultimately rejected, in Whitcomb. In Part II, I argue that the African American poor misunderstood the constitutional basis for challenging districting practices established in the one-person, one vote cases. In Part III, I advance an alternative theory of the constitutional right protected in constitutional doctrine. I then show that this right to effective participation is a more viable path to fair representation for the poor than the group-based representation model that the African American poor advanced in Whitcomb.

\footnotetext{
35. See infra Part II.A.

36. See infra Part II.A.

37. See infra Part II.B.

38. See infra Part III.

39. See infra Part III.
} 


\section{Claiming A Constitutional Right to Group-Based REPRESENTATION}

The last sustained effort to politically empower the poor dates back to the 1960s and early 1970s. As part of the War on Poverty, Congress in the Economic Opportunity Act of 1964 created and funded local nongovernment agencies labeled Community Action Agencies. ${ }^{40}$ These agencies had boards that made decisions on the allocation of federal funding to Community Action Programs in poor communities. ${ }^{41}$ For these boards, the Equal Opportunity Act mandated a unique and controversial design feature: "the maximum feasible participation" of the people impacted by the decisions of the board. ${ }^{42}$ Some designers of community action saw maximum feasible participation as a vehicle for the political empowerment of many groups, including the poor. ${ }^{43}$ According to one account, "[maximum feasible participation] meant starting with the most downtrodden. It meant that women ought to have an equal say-so with men. It meant that poor folks ought to have an equal say-so with upwardly mobile, upper middle-class [people]." 44

The political empowerment of the poor through these agencies, however, never came to fruition due to confusion surrounding the meaning of the maximum feasible participation mandate and weak federal enforcement. ${ }^{45}$ Resistance from local government actors, Southern and Republican opposition, and the election of a Republican President who opposed some of the central elements of the War on Poverty contributed to the failure of the community action experiment. ${ }^{46}$

40. 42 U.S.C. $\$ \S 2781-2837$ (1964) (repealed 1981). See Karen M. Tani, The House that "Equality" Built: The Asian American Movement and the Legacy of Community Action, in THE WAR ON POVERTY: A NEW GrassRoOTS History 1964-1980 411, 414 (Annelise Orleck \& Lisa Gayle Hazirjian eds., 2011) ("Between 1964 and 1968, the Office of Economic Opportunity channeled funds into more than one thousand local community action agencies (CAAs), which administered services ranging from legal assistance to job training.").

41. See id. at 415-16 (providing examples of how Asian American Community Action Agencies administered federal funds).

42. Michael L. Gillette, Launching the War on Poverty: An Oral History 95-99 (2d ed. 2010) (describing early debates on the meaning of "maximum feasible participation").

43. Id. at 99 .

44. Id. (alteration in original).

45. See Kenneth B. Clark \& Jeannette Hopkins, A Relevant War Against Poverty: A STUdy OF COMMUNITY ACTION Programs AND OBSERVABLE Social Change 107 (1969) (finding that the poor were rarely "numerically in a dominant position" on community action boards "[a]nd never are they in a dominant position in terms of actual power and influence").

46. See, e.g., Annelise Orleck, Conclusion: The War on the War on Poverty and American Politics Since the 1960s, in THE WAR ON POVERTY, supra note 40, at 437, 437-44 (describing the reshaping and elimination of anti-poverty programs beginning with the election of President Richard Nixon). 
As the Community Action programs teetered, poor African Americans in Marion County, Indiana pursued another strategy designed to empower the poor. They advanced a novel constitutional claim that the poor as a group had a right to representation in the legislative process. ${ }^{47}$ Selfdescribed "ghetto residents" of Marion County pushed a litigation strategy inspired by language in a then-recent Supreme Court case, Fortson $v$. Dorsey. ${ }^{48}$

In Fortson, the Court addressed a constitutional challenge to a multimember district - a district in which multiple legislators represented it. ${ }^{49}$ The challengers, residents of the multi-member district, argued that Indiana's creation and maintenance of the district violated their equal protection rights by making their votes less equal than others and therefore denying to them fair representation in the political process. ${ }^{50}$ The Court rejected the challengers' equal protection claim, finding no mathematical disparity in the representative-to-population ratio for the multi-member district (a critical factor in the Court's one-person, one vote constitutional determinations that I describe in Part III). ${ }^{51}$ The Court did, however, leave an opening for other types of challenges to multi-member districts. In dicta, the Court surmised, "[i]t might well be that, designedly or otherwise, a multi-member constituency apportionment scheme, under the circumstances of a particular case, would operate to minimize or cancel out the voting strength of racial or political elements of the voting population." "W2 "When this is demonstrated," the Court continued, "it will be time enough to consider whether the system still passes constitutional muster." 53

The poor African Americans of Marion County interpreted the dicta in Fortson as giving courts the authority to remedy group-based representation harms. ${ }^{54}$ And the district court agreed. The court determined that the ghetto residents comprised an identifiable racial minority group with distinct interests who experienced worse conditions

\footnotetext{
47. Whitcomb v. Chavis, 403 U.S. 124, 128-29 (1971).

48. See infra Part III.B. (describing in further detail the case and its context).

49. Fortson v. Dorsey, 379 U.S. 433, 434-35 (1965).

50. Brief for the Appellees at 6-8, Fortson, 379 U.S. 433 (No. 178), 1964 WL 81329, at *5-*8 (providing mathematical proof of the devaluation of individual votes in multi-member districts and connecting this mathematical proof to the denial of fair representation in the political process).

51. Fortson, 379 U.S. at 437-38.

52. Id. at 439

53. Id.

54. Brief of the Appellees at 11, Whitcomb v. Chavis, 403 U.S. 124 (1971) (No. 92), $1970 \mathrm{WL}$ 136610 , at $* 11$.
} 
and received less governmental services than other groups in the district. ${ }^{55}$ The court linked these burdens on the poor African Americans with their under-representation in the political process, which resulted in part from the multi-member districting scheme in Marion County, Indiana. ${ }^{56}$ The court found in the multi-member districting scheme that members of the Center Township ghetto area had disproportionately fewer representatives with only $4.75 \%$ of the senators and $5.97 \%$ of the representatives for an area of the County that comprised $17.8 \%$ of the population. ${ }^{57}$ This translated into the election of one state senator and four state representatives in the four elections between 1962 and 1968 for an area large enough "to elect approximately two members of the House of Representatives and approximately one senator" if single-member districts replaced the multi-member districts in Marion County. ${ }^{58}$

The combination of the political parties' strong control over the selection of candidates and the limited influence that poor African Americans had over the parties' candidate selection process exacerbated the under-representation of the group in the political process. ${ }^{59}$ In this political context, poor African Americans had less opportunity to elect "prospective legislators of their choice," which meant few legislators were accountable to the ghetto residents in the political process. ${ }^{60}$ The evidence of the ghetto residents' unequal representation in Marion County convinced the court to hold the multi-member districting scheme unconstitutional and mandate that the state draw uniformly sized districts throughout the state. ${ }^{61}$

A theory of the path to political empowerment and fair representation appeared to motivate the poor African Americans' challenge to the multimember district and the district court appeared to embrace the theory. By confining poor African Americans to the status of a small minority of the voting population, the multi-member districting scheme denied to them the opportunity to elect candidates responsive to their interests. To secure greater responsiveness, the ghetto residents wanted the court to force states to draw single-member districts that they could control, which would presumably be majority poor or close to it. ${ }^{62}$ Representatives of these

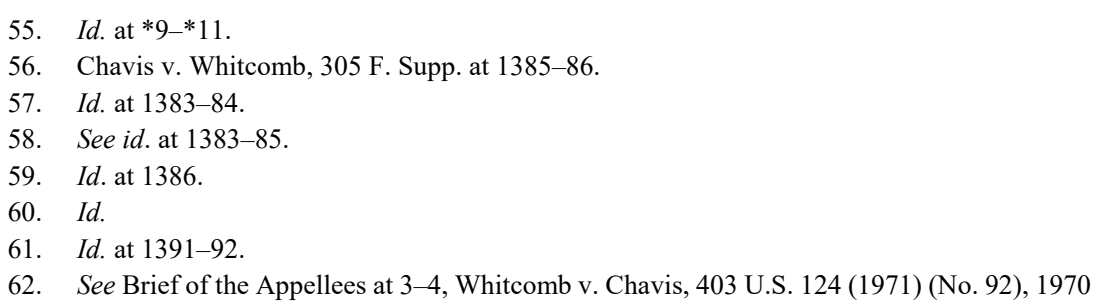


majority African American poor, single-member districts would have no choice but to be responsive to the needs and interests of the poor or risk being voted out of office.

The poor African Americans' apparent theory of the path toward fair representation would never be tested. The Supreme Court overturned the district court's decision and upheld the constitutionality of the multimember districting scheme in Marion County. ${ }^{63}$ Three aspects of the ghetto residents' constitutional claim concerned the Court and contributed to its decision to reject it. First, the African American poor's group rights claim to fair representation conflicted with prior judicially defined limits of the Equal Protection Clause to individual rights claims. ${ }^{64}$ Second, even if the Court were willing to break with precedent and recognize a groupbased right to fair representation, this would introduce tricky questions, including which groups are entitled to fair representation and what happens when different groups' claims to fair representation are irreconcilable. ${ }^{65}$ And finally, since group under-representation is an inevitable product of a winner-take-all democratic system in which there are winners and losers, the recognition of a constitutional claim of fair representation would require courts to distinguish between constitutional and unconstitutional under-representation arising from the same sourcelosing elections. ${ }^{66}$

WL 136610, at *3-4 (criticizing the multi-member districting scheme because it allowed the affluent and near affluent to dominate legislative seats and ignore the interests of the ghetto residents in Marion County and arguing that a shift to uniform single-member dsitricts would secure representation for the ghetto residents).

63. Whitcomb v. Chavis, 403 U.S. 124, 160 (1971).

64. Id. at 146, 149 ("The real-life impact of multi-member districts on individual voting power ha[d] not been sufficiently demonstrated.").

65. The Court in Whitcomb explained,

[t]he District Court's holding, although on the facts of this case limited to guaranteeing one racial group representation, is not easily contained. It is expressive of the more general proposition that any group with distinctive interests must be represented in legislative halls if it is numerous enough to command at least one seat and represents a majority living in an area sufficiently compact to constitute a single-member district. This approach would make it difficult to reject claims of Democrats, Republicans, or members of any political organization in Marion County who live in what would be safe districts in a single-member district system but who in one year or another, or year after year, are submerged in a onesided multi-member district vote. There are also union oriented workers, the university community, religious or ethnic groups occupying identifiable areas of our heterogeneous cities and urban areas. Indeed, it would be difficult for a great many, if not most, multimember districts to survive analysis under the District Court's view unless combined with some voting arrangement such as proportional representation or cumulative voting aimed at providing representation for minority parties or interests.

Id. at 156-57 (internal citations and footnotes omitted).

66. The Court in Whitcomb recognized and embraced as constitutionally acceptable our winnertake-all system of elections: 
The Court in Whitcomb maintained consistency with precedent and avoided difficult group-based representation questions by denying the ghetto residents' constitutional claim to fair representation. But in doing so, the Court only added to the confusion surrounding the constitutionality of districting practices. In its standard developed to address constitutional claims against multi-member districts, the Court in Fortson v. Dorsey appeared to embrace a constitutional principle grounded in protecting the rights of groups to fair representation. Multi-member districting schemes might run afoul of the Constitution, according to the Court in Fortson, when they cancel out or minimize the voting power of racial or political elements. ${ }^{67}$

What then triggered the Court's reluctance to endorse a group-based right to fair representation in Whitcomb? In the next two Parts, I argue that the ghetto residents in Whitcomb misunderstood the constitutional right articulated in Fortson. Rather than directly protecting the right to group-based representation, the Court in Fortson and its predecessors established protections for participatory rights that would lead to fairer representation in the political process.

\section{THE RIGHT TO FULL PARTICIPATION}

In two cases decided prior to Fortson, the Court entered the political thicket of districting. First, the court in Baker v. Carr declared constitutional claims against mal-apportioned districts justiciable. Then in Wesberry v. Sanders and Reynolds v. Sims, the Court struck down congressional and state legislative districting plans that created unequally populated single-member districts. In this Part, I argue the Court in those cases established the right to full and effective participation in the political process. In protecting these participatory rights from mal-apportioned districts, the Court recognized that a logical consequence would be greater fairness in representation. But what has been consistently overlooked by courts and scholars is that the Court in Wesberry and Reynolds never protected a constitutional right to fair and effective representation in the political process. Rather, the fair and effective representation advanced in

As our system has it, one candidate wins, the others lose. Arguably the losing candidates' supporters are without representation since the men they voted for have been defeated; arguably they have been denied equal protection of the laws since they have no legislative voice of their own. This is true of both single-member and multimember districts. But we have not yet deemed it a denial of equal protection to deny legislative seats to losing candidates, even in those so-called 'safe' districts where the same party wins year after year. Id. at 153 .

67. Fortson v. Dorsey, 379 U.S. 433, 439 (1965). 
the one-person, one-vote cases is that which arose from the Court's constitutional protection of the right to full and effective participation in the political process.

\section{A. The One-Person, One-Vote Cases}

Several decades of state refusal to draw equally apportioned districts finally brought the Supreme Court into a political thicket that it had long tried to avoid. ${ }^{68}$ The stranglehold that representatives from rural underpopulated districts had over state legislatures functioned as a prohibitive obstacle in some states to drawing equally apportioned districts. ${ }^{69}$ With no avenue for democratic correction of mal-apportioned districts in Tennessee, the Court in Baker v. Carr found a constitutional claim against the state's mal-apportioned districts to be justiciable. ${ }^{70}$

The Court entered into the political thicket cautiously recognizing the pitfalls of getting too involved in the political quagmire of districting disputes. The massive southern resistance to Brown v. Board of Education that threatened judicial legitimacy and integrity served as a reminder to the Court of the limits of judicial authority as an unelected, unaccountable institution equipped with neither the purse nor the sword. ${ }^{71}$ Thus, although the Court recognized that it was the only institution with the will to redress districting practices that undermined a fundamental principle of democracy, majority rule, it would have to do so in a way that would preserve judicial legitimacy and integrity.

As indicated by the Court's initial concern about reviewing districting controversies, preserving judicial legitimacy and integrity required two

68. See Colegrove v. Green, 328 U.S. 549, 556 (1946) (finding constitutional claims against mal-apportioned districts non-justiciable and famously declaring, "[c]ourts ought not to enter this political thicket").

69. See Stephen Ansolabehere \& James M. Snyder, Jr., The End of Inequality: One Person, One Vote And the Transformation of American Politics 54-55 (Ira Katznelson ed., 2008) (describing the different sources of mal-apportionment prior to 1960).

70. Baker v. Carr, 369 U.S. 186, 226-37 (1962). After Justice Frankfurter in Colegrove v. Green famously warned the Court against entering the "political thicket" of districting controversies that could embroil the Court in partisan politics, 328 U.S. 549, 554-56 (1946), the Court decided to do so. Responding to legislative unwillingness to properly apportion districts and the absence of a referendum process that would allow the people to override the legislature, the Court decided to involve itself in the constitutional resolution of districting controversies. See Baker, 369 U.S. at 237.

71. See Alexander Hamilton, No. 78, in The Federalist PAPERS 464, 465-66 (Clinton Rossiter ed., 1961) ("It proves incontestably that the judiciary is beyond comparison the weakest of the three departments of power; that it can never attack with success either of the other two; and that all possible care is requisite to enable it to defend itself against their attacks."); see, e.g., Tony Badger, Brown and Backlash, in MASSIVE RESISTANCE: SOUTHERN OPPOSITION TO THE SECOND RECONSTRUCTION 39 (Clive Webb ed., 2005) (describing the southern backlash to Brown and its origins in conservative resistance to racial change). 
things. $^{72}$ First, the Court would have to identify the harm from malapportioned districts and a rule to remedy the harm that can be directly derived from the Constitution. It was critical that the harm identified and the rule developed also appeal to the democratic intuitions of the People, since their support was necessary to defend courts from attack by the political institutions responsible for drawing the mal-apportioned districts and the representatives that benefited from the districting practice. Second, the rule developed would have to be one that states could easily follow and courts could easily apply. An objective and easily applicable test was necessary for courts to avoid discretionary judgments that could deepen judicial entanglement in the political partisanship surrounding districting and make the Court vulnerable to accusations of political bias.

Two years after Baker v. Carr, the Court embarked on the task of developing a constitutional rule applicable to mal-apportioned districts. In Wesberry, the Court addressed a challenge to Georgia's mal-apportioned congressional districts. ${ }^{73}$ The Court found that as a result of malapportionment, "[a] single Congressman [from the urban district including Atlanta] represents from two to three times as many... voters as are represented by each of the Congressmen from the other Georgia congressional districts." 74 That disparity, the Court held, ran afoul of "the command of Article I, $\S 2$ [of the Constitution], that Representatives be chosen 'by the People of the several States.",75 This constitutional command, the Court explained, meant that "as nearly as is practicable one man's vote in a congressional election is to be worth as much as another's." 76

Article I, Section 2 of the Constitution provided an odd legal basis for the Court to strike down mal-apportioned districts. This provision arose

72. In Colegrove v. Green, a plurality of the Court in an opinion written by Justice Felix Frankfurter asserted that constitutional claims against mal-apportioned districts were "of a peculiarly political nature and therefore not meet for judicial determination." Colegrove v. Green, 328 U.S. 549, 552 (1946). Given the close proximity of the decision to the Lochner era of aggressive judicial intervention into the democratic process and the political backlash that such intervention produced, it seems clear that the plurality was motivated by the desire to preserve the Court's integrity and legitimacy. See, e.g., Cass R. Sunstein, Lochner's Legacy, 87 CoLuM. L. REV. 873, 874 (1987) (“The received wisdom is that Lochner was wrong because it involved 'judicial activism': an illegitimate intrusion by the courts into a realm properly reserved to the political branches of government."); See also Guy Uriel E. Charles, Constitutional Pluralism and Democratic Politics: Reflections on the Interpretive Approach of Baker v. Carr, 80 N.C. L. Rev. 1103, 1109 (2002) (“Justice Frankfurter's apologia in Colegrove . . . is fundamentally an argument about the proper role of the judiciary in the political process.").

73. Wesberry v. Sanders, 376 U.S. 1, 2-3 (1964).

74. Id. at 7 .

75. Id. at $7-8$.

76. Id. 
from the famous Connecticut Compromise (also known as the "Great Compromise") between the representational demands of large and small population states during the Constitutional Convention. ${ }^{77}$ The compromise produced a bicameral legislature in which representation in the House of Representatives was by population and representation in the Senate was divided equally among the states. ${ }^{78}$

For the House of Representatives, Article I, Section 2 requires that every state have the same number of seats in proportion to its population as every other state. ${ }^{79}$ But Article I, Section 2 says nothing about how the states must apportion representation within their states. Nonetheless, from the constitutional text and debates during the Constitutional Convention, the Court in Wesberry derived a constitutional principle that supported extending Article I, Section 2's reach to controversies about the apportionment of representation within the states. ${ }^{80}$ In identifying the constitutional wrong from mal-apportioned districts, the Court focused on the harmful effect on the individual's vote and the relationship between this harm, democratic government, and our constitutional commitments. ${ }^{81}$ "To say that a vote is worth more in one district than in another would not only run counter to our fundamental ideas of democratic government," the Court explained, "it would cast aside the principle of a House of Representatives elected 'by the People,' a principle tenaciously fought for and established at the Constitutional Convention." 82

Relying on quotes from prominent constitutional convention participants such as George Mason, James Madison, and James Wilson, the Court in Wesberry found, "[o]ne principle was uppermost in the minds of many delegates: that, no matter where he lived, each voter should have a voice equal to that of every other in electing members of Congress." ${ }^{\prime \prime}$ According to the Court, the Framers secured this principle of "fair

77. See Richard BeEman, Plain, Honest Men: The Making of the American CONSTITUTION 200-25 (1st ed. 2009) (providing an account of the Connecticut Compromise).

78. $I d$.

79. U.S. CONST. art. I, $\S 2$, cl. 3 ("Representatives ... shall be apportioned among the several States which may be included within this Union, according to their respective Numbers .....").

80. Wesberry, 376 U.S. at 9-17.

81. Id. at 8 .

82. Id.

83. Id. at 10-11. In Wesberry, the Court provided the following quotes of the Convention delegates: (1) James Madison: "If the power is not immediately derived from the people, in proportion to their numbers, we may make a paper confederacy, but that will be all." Id. at 10; (2) George Mason: "[The House of Representatives] was to be the grand depository of the democratic principle of the [Government].” Id.; (3) James Wilson: “"[E]qual numbers of people ought to have an equal [number] of representatives...' and representatives 'of different districts ought clearly to hold the same proportion to each other, as their respective constituents hold to each other."' $I d$. at 10-11. 
representation of the people" through a periodic census that assured "that 'number of inhabitants' should always be the measure of representation in the House of Representatives." 84 From this evidence of the Framers' intent, the Court set forth a constitutional rule to be applied to districting. The Court described the "Constitution's plain objective" as "making equal representation for equal numbers of people the fundamental goal for the House of Representatives." 85

The Court in Wesberry thus appeared to recognize both participatory and representation harms from mal-apportioned districts. But while there is some ambiguity, the reasoning in the case suggests that the Court adopted a particular view about the relationship between the two harms arising from malapportionment that informed its constitutional enforcement role. For the Court, the primary target appeared to be the participatory harm produced by malapportioned districts arising from the unequal weighting of individuals' votes. The remedy of equally apportioned districts most directly redressed the participatory harm by ensuring that everyone's vote counted the same. This remedy would also lead to more fairness in representation, defined as equal representation for individuals in the political process. Such equal representation ultimately translates into a system in which a majority of individuals are able to elect a majority of representatives.

In Wesberry, the Court did not seem concerned by the harm particular groups might suffer if not represented. Malapportioned districts did dilute the representation of urban interests in state legislatures and Congress. ${ }^{86}$ But the Court never said anything about this effect of malapportionment on the representation of groups or how equally apportioned districts remedied the under-representation of particular groups. For the Court to redress group-based representation harms, it would have had to construct a baseline measure of fair representation for groups. ${ }^{87}$ Further, given that it is unlikely that equally apportioned districts alone would guarantee fair representation for all groups in the political process, the Court would also need to impose additional constraints on the operation of democratic politics or explain why some unfairly represented groups were not entitled

84. Id. at $13-14$.

85. Id. at 18 .

86. ANSOLABEHERE \& SNYDER JR., supra note 69 , at 68 (describing urban interests as losers from malapportionment).

87. See, e.g., Richard Thompson Ford, Geography and Sovereignty: Jurisdictional Formation and Racial Segregation, 49 STAN. L. REV. 1365, 1380 (1997) (describing the difficulty of identifying a baseline of fairness for groups in a districting map). 
to constitutional protection. ${ }^{88}$ The Court in Wesberry did neither. The absence of judicial reasoning focused on group-based representation harms and the lack of a remedy responsive to such harms therefore suggests the Court's exclusive focus was on individual participatory harms arising from malapportioned districts.

The reasoning in the case of Reynolds $v$. Sims further supports the argument that the Court's primary constitutional target was the harms individuals experienced from unequal participation. ${ }^{89}$ In Reynolds, the Court addressed the constitutionality of malapportioned state legislative districts in Alabama. ${ }^{90}$ Since Article I, Section 2 of the U.S. Constitution only applied to congressional apportionment, the Court had to look elsewhere for a constitutional textual basis to review state malapportioned districts. $^{91}$ Two years earlier in Baker v. Carr, the Court hinted at the Fourteenth Amendment Equal Protection Clause and its "well developed and familiar" judicial standards as the constitutional basis for adjudicating challenges to malapportioned state legislative districts. ${ }^{92}$ In Reynolds, the Court took the next step of identifying the harms from malapportioned districts and the constitutional standard applicable to such districts.

The Court in Reynolds advanced an elaborate description of the participatory rights implicated by malapportionment and the relationship between participatory rights and democratic government. ${ }^{93}$ The Court explained, " $[t]$ he right to vote freely for the candidate of one's choice is of the essence of a democratic society, and any restrictions on that right strike at the heart of representative government." 94 This right to vote, the Court continued, "can be denied by a debasement or dilution of the weight of a citizen's vote just as effectively as by wholly prohibiting the free exercise of the franchise." ${ }^{95}$ The Court acknowledged that a state, in responding to the decision, might "require the restructuring of the geographical distribution of seats in a state legislature." 96 But the Court made clear that the target for judicial evaluation should not be the structure of

88. The Court's decision in Fortson was a recognition that equally apportioned districts would not lead to the fair representation in the political process of members of all groups. See infra Part II.B.

89. Reynolds v. Sims, 377 U.S. 533 (1964).

90. Id. at 537.

91. Article I, Section 2 established a constitutional rule for the apportionment of the House of Representatives. See U.S. CONST. art. I, § 2 cl. 3 ("Representatives . . . shall be apportioned among the several States which may be included within this Union, according to their respective Numbers.").

92. Baker v. Carr, 369 U.S. 186, 226 (1962).

93. Reynolds, 377 U.S. at 554-55.

94. Id. at 555.

95. Id.

96. Id. at 561 . 
representation. Rather, the "judicial focus must be concentrated upon ascertaining whether there has been any discrimination against certain of the State's citizens which constitutes an impermissible impairment of their constitutionally protected right to vote." constitutional mandate, the Court announced, is "full and effective participation" for all citizens in the democratic process, meaning that "each citizen ha[s] an equally effective voice in the election of [legislators]." 98

The Court acknowledged the effect on representative government of state compliance with the constitutional requirement of full and effective participation. As in Wesberry, the logical consequence from granting all citizens an equally effective voice in electing representatives is majority rule. In Reynolds, the Court explained, a system in which "a majority of the people of a State could elect a majority of that State's legislators" is something that legislative apportionment with its aim of "achieving... fair and effective representation for all citizens" should strive for. ${ }^{99}$ The alternative of malapportioned districts that "sanction minority control of state legislative bodies," the Court surmised, "would appear to deny majority rights in a way that far surpasses any possible denial of minority rights that might otherwise be thought to result."100

The Reynolds majority's discussion of the consequence of malapportionment for representative government exposed it to the critique that the Court was imposing a particular political philosophy on its citizens. Dissenting in a parallel case, Justice Potter Stewart keyed in on the Court's assertion about representative government. Justice Stewart criticized the majority for "convert[ing] a particular political philosophy into a constitutional rule, binding upon each of the [fifty] States . . .."101 Since "no one theory has ever commanded unanimous assent among political scientists, historians, or others," Justice Stewart argued, the states should have leeway in deciding on the appropriate form of representative government consistent with their "distinct history, distinct geography, distinct distribution of population, and distinct political heritage." 102 One such alternative theory that Justice Stewart identified views "[r]epresentative government [as] a process of accommodating group

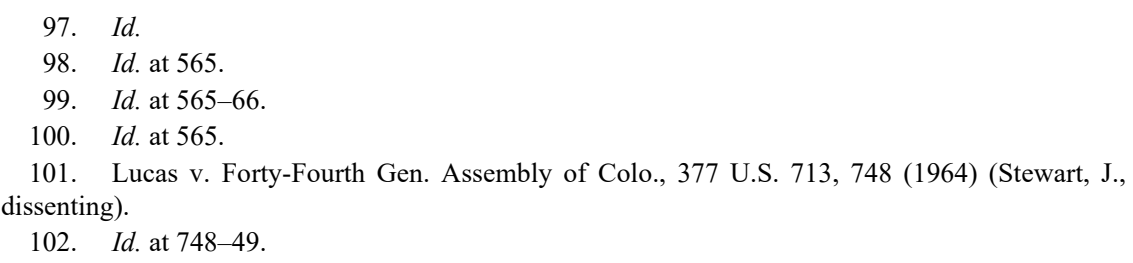


interests through democratic institutional arrangements."103 In this representative system, the goal is "to channel the numerous opinions, interests, and abilities of the people of a State into the making of the State's public policy." 104 This representative process can be advanced through malapportioned districts that deny majority rule because such districts might provide opportunities for "fair, effective, and balanced representation of the regional, social, and economic interests within a State." 105

Justice Stewart's critique of the Reynolds majority was powerful, but it ultimately misunderstood the basis for the decision. The Reynolds majority did not invalidate malapportioned districts because they failed to provide fair and effective representation in the form of majority rule, a democratic principle nowhere explicitly contained in the Constitution. Rather, the Court struck down malapportioned districts because they imposed unconstitutional participatory harms on individuals by diluting their vote.

As a reluctant intervener into districting controversies, the Court sought to confine its interference into democratic politics to protecting the rights of individuals. As the Court explained in Reynolds, "[a] predominant consideration in determining whether a State's legislative apportionment scheme constitutes an invidious discrimination violative of rights asserted under the Equal Protection Clause is that the rights allegedly impaired are individual and personal in nature." 106 The Court's review of apportionment schemes therefore had to be "concentrated upon ascertaining whether there has been any discrimination against certain of the State's citizens which constitutes an impermissible impairment of their constitutionally protected right to vote." 107 The Court did recognize that remedying individual rights through a constitutional mandate of equally apportioned districts would advance a representative government principle of majority rule. ${ }^{108}$ But for the Court, majority rule was simply a consequence of constitutional protection for individual voting rights, not the goal. The Court sought to avoid, as much as it could, imposing any particular political philosophy on its citizens.

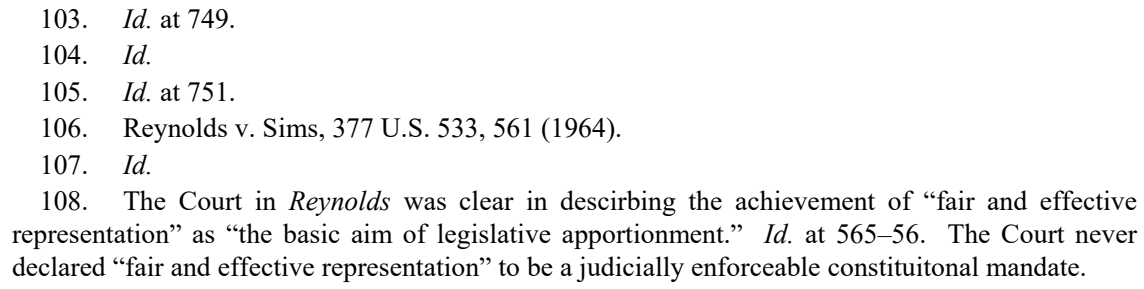




\section{B. The Curious Case of Fortson v. Dorsey}

A year after deciding Reynolds, the Court addressed the challenge to multi-member districts in Fortson v. Dorsey. ${ }^{109}$ In Fortson, the Court determined that multi-member districts that maintained the same population to representative ratio as single-member districts were presumptively constitutional. ${ }^{110}$ But the Court opened the door to judicial recognition of a constitutional claim under the Fourteenth Amendment Equal Protection Clause, even when districts are properly apportioned. As already quoted, the Court explained, "[i]t might well be that, designedly or otherwise, a multi-member constituency apportionment scheme, under the circumstances of a particular case, would operate to minimize or cancel out the voting strength of racial or political elements of the voting population."111 In Whitcomb, the poor African Americans of Marion County, Indiana relied on this dictum to claim that multi-member districts denying them the opportunity to elect candidates of their choice violated the Equal Protection Clause. ${ }^{112}$

Did the Court in Fortson expand its recognition of the constitutional harms from districting practices to encompass group-based representation harms? Some support for this idea can be found in Justice Stewart's decision to join the opinion. As indicated in his dissent to the one-person, one-vote cases, Justice Stewart did not support the one-person, one-vote rule. He was instead a proponent for recognizing a philosophy of democratic politics centered on the accommodation of group interests. ${ }^{113}$ But if the Court in Fortson recognized as a constitutional harm the denial to groups of their representational rights, it would have stunningly reversed itself one year after narrowly construing the constitutional harm in individual participatory terms in Reynolds $v$. Sims. Further, interpreting Fortson as establishing a constitutional rule under the Equal Protection Clause protecting groups from discrimination would have represented a striking departure from the Court's past constitutional jurisprudence. Up until Fortson, the Court had consistently protected individuals from discrimination because of their membership in a group, but it had never explicitly protected groups from discrimination. ${ }^{114}$

\footnotetext{
109. Fortson v. Dorsey, 379 U.S. 433 (1965).

110. Id. at $435-36$.

111. Id. at 439 .

112. See supra Part I.

113. See supra notes $101-05$ and accompanying text.

114. For an account of the competing individual-based and group-based conceptions of the Equal Protection Clause, see generally Owen M. Fiss, Groups and the Equal Protection Clause, 5 PHIL. \&
} 
While on its face it might seem to be a strange place to look, a famous Sherlock Holmes short story can perhaps provide a clue as to whether the Court intended to recognize group-based representation harms from districting practices. In the short story "Silver Blaze," Holmes sets about solving the mystery of the disappearance of a famous prize-winning racehorse and the apparent murder of its trainer the night before an important race. ${ }^{115}$ One piece of evidence that helps Holmes, and his omnipresent assistant, Dr. Watson, solve the case is the "curious incident of the dog in the night-time." 116 The details of the curious incident unfold in a conversation between a Scotland Yard detective, Gregory, and Holmes:

Gregory: Is there any other point to which you wish to draw my attention?

Holmes: To the curious incident of the dog in the night-time.

Gregory: The dog did nothing in the night-time.

Holmes: That was the curious incident. ${ }^{117}$

The dog, doing nothing, indicated that a person familiar to the dog must have been involved in the crime. Otherwise, the dog would have barked. Courts have relied on the "Silver Blaze" story to develop a canon of statutory interpretation known as the "dog that did not bark." 118 As applied in the statutory interpretation context, the failure of the legislature to comment upon or debate a change to a major policy ostensibly produced by a statute indicates that the statute did not change the major policy. ${ }^{119}$ Courts treat the lack of legislative comment and debate on an important policy issue as the equivalent of the dog not barking in "Silver Blaze" and an indicator of the legislature's intent that the status quo on the issue remains undisturbed. ${ }^{120}$

The "dog that did not bark" canon can also be persuasively applied to the Court's constitutional jurisprudence. Reasoned analysis is central to

\footnotetext{
PuB. AFF. 107 (1976).

115. Arthur Conan Doyle, Silver Blaze, in The Complete Sherlock Holmes 335, 335-50 (Doubleday \& Co. 1930).

116. Id. at 347.

117. Id.

118. See generally Anita S. Krishnakumar, The Sherlock Holmes Canon, 84 GEO. WASH. L. REV. 1 (2016) (providing a detailed account of the "dog that did not bark" canon).

119. Id. at $2-3$.

120. Id. at 3 .
} 
judicial decision-making and it preserves judicial legitimacy and standing in a democracy as a branch of government comprised of unaccountable, unelected, life tenured judges. ${ }^{121}$ Failure to reason through major jurisprudential change that results in the adjustment of old, or the adoption of new, constitutional rules or standards will subject courts to accusations of arbitrariness. ${ }^{122}$ It therefore should be presumed that reasoned analysis will accompany any major changes in doctrine, particularly the constitutional doctrine for which the Court has asserted supremacy in the form of the final say about what the Constitution means. ${ }^{123}$ The Court in Wesberry and Reynolds reasoned through and justified its intervention into districting controversies by providing a textual, historical, and doctrinal basis for the individual participatory harms it recognized in those cases. ${ }^{124}$ The Court provided no such reasoning or justification for the recognition of a new constitutional group-based representational harm in Fortson or in any other case that followed. In other words, the dog did not bark, which strongly suggests the Court did not intend in Fortson to recognize a groupbased representational harm.

A theory of the harm underlying Fortson should therefore be understood in terms consistent with Wesberry and Reynolds. In the next Part, I argue that like the one-person, one-vote standard in Wesberry and Reynolds, Fortson's constitutional standard also targets an individual participatory harm. Whereas the Court in Wesberry and Reynolds adopted a constitutional rule that protects the individual right to full participation in the political process, the Court in Fortson established a constitutional standard designed to protect the right to effective participation in the political process. After identifying the right to effective participation, I then examine the meaning of this right and how judicial protection of poor individuals' right to effective participation can lead to greater fairness of representation of the group in the political process.

121. See Micah Schwartzman, Judicial Sincerity, 94 VA. L. REV. 987, 1005-08 (2008) (explaining the value of public justification through judicial reasoned analysis).

122. See Mathilde Cohen, Sincerity and Reason-Giving: When May Legal Decision Makers Lie, 59 DePAul L. REV. 1091, 1109 (2010) ("[I]n most democratic legal systems, the requirement to give reasons has been constructed on the principle that public institutions should not enjoy arbitrary power.").

123. See Cooper v. Aaron, 358 U.S. 1, 18 (1958) (interpreting Marbury v. Madison as "declar[ing] the basic principle that the federal judiciary is supreme in the exposition of the law of the Constitution").

124. See supra notes $68-101$ and accompanying text. 


\section{The Right TO EFFECTIVE PARTICIPATION}

In the years immediately following the ratification of the Fifteenth Amendment in 1870, Congress passed a series of acts to enforce the amendment. ${ }^{125}$ Revised versions of two of these acts would later provide the basis for judicial protections of the right to vote under the Constitution. Section 19 of the Criminal Code criminalized any conspiracy between two or more persons "to injure, oppress, threaten, or intimidate any citizen in the free exercise or enjoyment of any right or privilege secured to him by the Constitution or laws of the United States." 126 Section 20 of the Criminal Code made it a crime for anyone who, acting "under color of any law ... willfully subjects, or causes to be subjected, any inhabitant of any State ... to the deprivation of any rights, privileges, or immunities secured or protected by the Constitution and laws of the United States." 127

In two cases in the 1940s, the Court constructed a constitutional right to vote as part of its interpretation of the two statutes. In the first case, United States v. Classic, the United States brought an indictment against the Louisiana state commissioner of elections under Sections 19 and 20 of the Criminal Code alleging that he had "willfully altered and falsely counted and certified the ballots of voters cast in [a] primary election."128 The Court, relying on Article I, Section 2's mandate that congresspersons be chosen by the people of the several states, defined the constitutional right protected under the Criminal Acts to broadly include "the right of qualified voters. . . to cast their ballots and have them counted . . .."129

In the second case, United States $v$. Saylor, the United States brought an indictment under Section 19 of the Criminal Code against conspirators for allegedly depriving individuals of "their right to have their expressions of choice given full value and effect by not having their votes impaired, lessened, diminished, diluted and destroyed by fictitious ballots fraudulently cast and counted, recorded, returned, and certified." 130 The Court determined that the constitutional rights protected under the Criminal Acts also included the right to vote undiluted by fraudulent practices. ${ }^{131}$

\footnotetext{
125. For a historical account of statutes enforcing the Reconstruction-era amendments, see ERIC FONER, RECONSTRUCTION, AMERICA'S UNFINISHED REVOLUTION 1863-1877 454-59 (Henry Steel Commager \& Richard B. Morris eds., 1988).

126. Act of Mar. 4, 1909, ch. 321 ch. $3 \S 19,35$ Stat. 1092 (1909).

127. Id.

128. United States v. Classic, 313 U.S. 299, 307 (1941).

129. Id. at 315

130. United States v. Saylor, 322 U.S. 385, 386 (1944).

131. Id. at 389 ("For election officers knowingly to prepare false ballots, place them in the box,
} 
In Wesberry and Reynolds, the Court relied on these cases in its articulation of the participatory harm from malapportioned districts. According to the Court, the constitutional problem with malapportioned districts was their effect in lessening, diminishing, or diluting the value of individuals' votes. ${ }^{132}$ But the Court in Classic and Saylor was not only concerned that fraudulent ballot practices would deny an individual the full value of her vote by lessening, diminishing, or diluting its value. The Court was also concerned that fraudulent ballot practices might impair or destroy an individual's vote. We can understand how fraudulent ballot practices might impair or destroy an individual's vote by considering the potential implications of the practice on the influence of an individual's vote.

To take an extreme example, if a representative knows that she can secure election through ballot stuffing practice that guarantees to her a majority of the vote irrespective of turnout, then she has no incentives to respond to, account for, or consider the interests or needs of actual voters. While this example might seem fantastical in the context of the United States, we do see practices that come close to this extreme in other lessdeveloped democracies. ${ }^{133}$

We, however, do not need to go to this extreme to see how an individual's vote might be destroyed or impaired in the context of fraudulent ballot practices. It could be that the fraudulent practice combined with turnout from supporters provides the election guarantee. In this hypothetical context, the representative retains the electoral incentives to be responsive and accountable to supporters and the vote of individual supporters continues to be meaningful in securing influence over their representative. But the representative has no incentive to be responsive, accountable, or considerate to the interests of opponents. Since the representative will never need individual opponents' votes because opponents cannot change election outcomes, the votes of these

and return them, is certainly to prevent an honest count by the return board of the votes lawfully cast.").

132. See Wesberry v. Sanders, 376 U.S. 1, 17 (1964) (citing to Classic and Saylor and holding, "not only can th[e] right to vote not be denied outright, it cannot, consistently with Article I, be destroyed by alteration of ballots or diluted by stuffing of the ballot box. No right is more precious in a free country than that of having a voice in the election of those who make laws under which, as good citizens, we must live.") (citations omitted); Reynolds v. Sims, 377 U.S. 533, 555 (1964) (citing to Classic and Saylor and holding that "[t]he right to vote can neither be denied outright, nor destroyed by alteration of ballots, nor diluted by ballot-box stuffing") (citations omitted).

133. See e.g., Misha MyAGKov \& PETER C. ORDESHOOK, RuSSIAN EleCtions: AN OXYMORON OF DEMOCRACY (2008), https://www.ucis.pitt.edu/nceeer/2008_822-11_Ordeshook.pdf (discussing the prevalence of fraud in Russian elections). 
individual members of the opposition have been destroyed or impaired by being rendered meaningless.

While the focus in Classic and Saylor was on fraud, such fraud is not a necessary condition for rendering an individual's vote meaningless. Focusing on districts, a state legislature or redistricting commission could construct districts in a way that renders the votes of individuals meaningless. In the United States, political parties and the candidates that affiliate with them are the primary vehicles for representation. ${ }^{134}$ The level of individual or group affiliation with one of the two dominant parties varies from strong supporters like evangelical Christians for Republicans and African Americans for Democrats, to weak supporters whose affiliations have historically shifted or been divided, such as working class whites. ${ }^{135}$ If the state legislature draws districts to include, for example, a sufficient base of strong supporters guaranteeing a party representative reelection, the votes of non-supporters in the district can be rendered meaningless. ${ }^{136}$ Since the representative knows she can win without the votes of non-supporters, she has no incentive to be responsive, accountable, or even considerate of the needs and interests of nonsupporters. As a result, non-supporters are denied their opportunity to influence elections and even the minimal form of representation in the form of the representative's consideration of their needs and interests in her policy decisions. In the language of Fortson, the state has drawn the district in a way that "minimize[s] or cancel[s] out" the vote of particular elements (individuals) in the district. ${ }^{137}$ The right to effective participation should thus be understood as the right of individuals to exercise through their vote enough influence over the representative to ensure that they cannot be entirely ignored without electoral consequences for the representative.

A state's infringement on the right to effective participation cannot be as easily ascertained as a state's infringement on the right to full participation. But there are two important indicators of when an individual's right to effective participation might have been infringed. First, consistently low turnout of members of certain groups relative to the

134. See, e.g., JOHN H. ALDRICH, Why PARTIES? A SECOND LOOK 3 (2011) (“The political party as a collective enterprise, organizing competition for the full range of offices, provides the only means for holding elected officials responsible for what they do collectively.").

135. Id. at 9-10 (describing the evolving coalitions associated with the two parties in the United States).

136. See Samuel Issacharoff, Gerrymandering and Political Cartels, 116 HARV. L. REV. 593, 644-45 (2002) (criticizing legislators' self-interested drawing of safe districts).

137. Fortson v. Dorsey, 379 U.S. 433, 439 (1965). 
overall turnout level in the district is an indicator that members of the groups have been marginalized to the extent that they do not deem it worthwhile to vote. ${ }^{138}$ This very low turnout for members of a group suggests that the group is caught in the vicious cycle of underrepresentation in which lack of legislative responsiveness has contributed to low turnout. ${ }^{139}$ Second, consistently high margins of victory for representatives in the district might be an indicator that the lack of district competitiveness is a contributing factor to the representative's nonresponsiveness to members of the marginalized group, which then leads marginalized group members to abstain from voting. ${ }^{140}$ The appropriate triggers for constitutional review in terms of level of turnout and margins of electoral victory should be decided after rigorous judicial engagement with facts on the ground. But once determined, courts should consistently apply the trigger in future cases. ${ }^{141}$

When a state through its districting practices denies members of a group the right to effective participation, a different remedy from the one the poor African Americans proposed in Whitcomb should follow. The poor African Americans in Marion County, Indiana claimed a group entitlement to more proportionate representation in the state legislature through single-member districts that they could electorally control. ${ }^{142}$ This remedy depends on judicial recognition of a constitutional right that is distinct from the right to effective participation advanced in Classic and Saylor and ultimately embraced in Wesberry and Reynolds. ${ }^{143}$ The right of individuals to effectively participate does not translate into a guarantee of electoral control for groups over a proportional number of districts.

138. See supra note 25 (identifying as a source of non-voting, a perception by individuals that there are no benefits to be derived from voting because of the non-responsiveness of legislators to their interests and needs).

139. See supra note 26-27 (describing the vicious cycle of underrepresentation).

140. Social science studies have found that competitive districts increase voters interest in politics and their likelihood to vote. See Philip Edward Jones, The Effect of Political Competition on Democratic Accountability, 35 POL. BEHAV. 481, 509 (2013) (finding on the basis of survey data that "voters in competitive states are more interested in politics"); Heather K. Evans, Michael J. Ensley, \& Edward G. Carmines, The Enduring Effects of Competitive Elections, 24 J. ElECTIONS, PUB. OPINION \& PARTIES 455, 469 (2014) (finding that competitive campaigns had a statistically significant positive effect on citizens' political engagement a year after the election).

141. This may require ongoing case law development similar to that which happened in the development of the quantitative threshold for equally apportioned state legislative and congressional districts. See Kirkpatrick v. Preisler, 394 U.S. 526, 530-32 (1969) (settling on an apportionment standard for congressional districts in which any variation from equality is presumptively unconstitutional); Chapman v. Meier, 420 U.S. 1, 26-27 (1975) (settling on an apportionment standard allowing for de minimis variation from equality for state legislative districts).

142. See supra note 59.

143. See supra Part II.A. 
Instead, it should translate into an opportunity to be heard through the construction of districts in which candidates are forced to compete for everyone's votes.

A further complication with the challenger's proposed remedy in Whitcomb is that our constitutional system is not designed to secure proportional representation for groups in the political process. ${ }^{144}$ Imposition of proportional representation would require the Court to adopt a particular political philosophy nowhere grounded in the Constitution that would potentially have even greater consequences for our electoral system than the requirement of one-person, one-vote.

Finally, it is not clear that the remedy of providing groups an opportunity to control districts would be the most effective means for securing representation for all groups. Congress established a statutory right to group-based representation for racial minority groups in the Voting Rights Act that proved successful at increasing both the descriptive and substantive representation of African Americans in the political process. $^{145}$ But African Americans are distinct from the poor in an important respect. Prior to Congress's establishment of a group representation guarantee in the VRA, civil rights groups mobilized African Americans to vote and to vote cohesively against elected leaders that ignored and neglected the group's interests and needs. ${ }^{146}$ Thus, when the time came, African Americans were able to take advantage of the statutory remedy of opportunity-to-control districts and elect candidates of their choice. ${ }^{147}$

Unlike African Americans, the poor are not the beneficiaries of a social movement mobilizing them to vote. Forcing states to draw districts that the poor should be able to control on the basis of their numbers is therefore much less likely to secure representation for the poor than it did for African Americans. Evidence supporting that prediction can be found

144. See City of Mobile v. Bolden, 446 U.S. 55, 75-76 (1980) ("The Equal Protection Clause of the Fourteenth Amendment does not require proportional representation as an imperative of political organization. The entitlement . . . is not to be found in the Constitution of the United States.').

145. See, e.g., Sophie Schuit \& Jon C. Rogowski, Race, Representation, and the Voting Rights Act, 61 AM. J. POL. SCI. 513, 519-21 (2017) (finding that the Voting Rights Act increased the representation of African Americans).

146. See, e.g., Kenneth T. Andrews, The Impacts of Social Movements on the Political Process: The Civil Rights Movement and Black Electoral Politics in Mississippi, 62 AM. SoC. REV. 800, 80405 (1997) (describing the efforts of civil rights organizations to mobilize African Americans in Mississippi in the 1960s).

147. See, e.g., Pei-te Lien, et al., The Voting Rights Act and the Election of Nonwhite Officials, 40 PS: POL. SCI. \& POL. 489, 489-90 (2007) (describing the increase in the number of racial minority representatives and linking this to the substantial increase in the number of opportunity-to-control majority-minority districts after the 1990 round of redistricting). 
in a study finding that representatives of districts with more poor individuals are less likely to support legislation favorable to the poor than representatives of districts with fewer poor people. ${ }^{148}$ This suggests that representatives feel they can safely ignore poor voters without electoral consequences even when the poor comprise a relatively high proportion of individuals in the district.

Before a VRA-like remedy of opportunity-to-control districts can be effective in securing representation for the poor, what is needed is a constitutional remedy that can incentivize parties, candidates, and interest groups to mobilize the poor. Forcing states to make districts more competitive is one such remedy that might produce the necessary incentives for candidates to mobilize and for elected officials to ultimately represent the poor. ${ }^{149}$ Greater competitiveness will increase the intensity and expansiveness of candidate mobilization efforts and raise the costs to candidates of ignoring voters or potential voters. ${ }^{150}$ When governing, electoral risk aversion should lead representatives to consider and incorporate the needs and interests of as many constituents as possible. This does not mean that representatives will make policy decisions advancing the needs and interests of all of their constituents; the needs and interests of constituents will, at times, necessarily conflict making it impossible to do so. But what it might mean is that representatives will have electoral incentives to consider the degree and intensity of needs and interests of a broader constituency when making policy decisions. This could lead to changes in representatives' roll call votes, decisions on what legislation to advance and consider, and determinations about the nature and form of their policy platforms, among other more broadly responsive activities.

148. Bertrall L. Ross II \& Su Li, Measuring Political Power: Suspect Class Determinations and the Poor, 104 CAL. L. ReV. 323, 368-69 (2016).

149. Several studies overcoming endogeneity biases that plagued prior studies have found a robust and statistically significant positive correlation between competitiveness and turnout. See, e.g., Chrisrine Fauvelle-Aymar \& Abel Francois, The Impact of Closeness on Turnout: An Empirical Relation Based on a Study of Two-Round Ballot, 127 PUB. CHOICE 469, 484 (2006); Gabor Simonvits, Competition and Turnout Revisited: The Importance of Measuring Expected Closeness Accurately, 31 ELECTORAL STUD. 364, 369-70 (2012).

150. See, e.g., Gary W. Cox \& Michael C. Munger, Closeness, Expenditures, and Turnout in the 1982 U.S. House Elections, 83 AM. POL. SCI. REV. 217, 226 (1989) (finding evidence that closeness of elections leads candidates to increase their campaign expenditures, which translates into increased mobilization activity that enhances turnout). 


\section{CONCLUSION}

The time for judicial enforcement of the right to effective participation is now. Over the past sixty years, there has been a significant decline in the competitiveness of legislative races. ${ }^{151}$ According to one important barometer of competitiveness, incumbent re-election rates, competitiveness in U.S. House of Representative elections has been abysmally low since the mid-1970s. In only two elections since 1974 has the re-election rate for members of the House dipped below 90 percent. ${ }^{152}$ In over half of the elections during this period (11 out of 21$)$, the reelection rate in the House stood at 95 percent or higher. ${ }^{153}$ This lack of competitiveness has coincided with relatively low turnout among politically marginalized and alienated poor individuals. ${ }^{154}$ From this confluence of low competitiveness and turnout among the poor, legislation like the Tax Cut and Jobs Act is passed that burdens the poor without any elected officials speaking for the poor. It is impossible to say what type of tax law Congress would have passed if more of its members had been subject to competitive elections, but it is extremely unlikely that both political parties would have entirely ignored the negative effect of the law on the poor.

As was the case when the Court decided to enter the political thicket of districting in the $1960 \mathrm{~s}$, courts are needed to remedy political process dysfunction because the People's representatives have no incentives to do so. The construction of competitive districts is antithetical to the interests of representatives who prefer safe electoral districts that can guarantee them re-election. Therefore, to solve the democratic dilemma of political marginalization, courts need to step in and enforce the overlooked constitutional right of individuals to effectively participate in the political process.

151. See, e.g., Alan I Abramowitz, et al., Incumbency, Redistricting, and the Decline of Competition in U.S. House Elections, 68 J. POL. 75, 75-76 (2006) (describing the steady decline in competitive congressional races since World War II).

152. See Reelection Rates Over the Years, OPENSECRETS.ORG: CENTER FOR RESPONSIVE POLITICS, https://www.opensecrets.org/overview/reelect.php (last visited May 14, 2018).

153. Id.

154. See supra note 133 and accompanying text. 